\title{
Woody Allen as Impossible Cassandra
}

\author{
By Alessandro Zir \\ Fall 2010 Issue of KINEMA
}

\section{IMPROVING ON ST. PETER: WOODY ALLEN AS IMPOSSIBLE CASSANDRA}

Woody Allen always invited a dose of nihilism, disguised in the very laugh of the audience. A sadism directed to nobody but he himself, who people identified with his characters. Whatever is the truth concerning his older movies, in the last ones, the audience finally discovers him at his best, maturated from all abject humility. Being or not in the movie, he now accompanies it, and accompanies the public, as this Splendini of Scoop (2006): a false father, awkward, lonely, sceptical, of the "narcissistic persuasion", but in the same way disarmed, caring, reliable, if clumsy. For sure, he is not going to hurt you. He fails, of course, when it comes to save you, but he will die trying. He is the loquacious quintessence, almost a spirit of séance, of the gentle nitwit, in the best tradition of Chaplin.

Cassandra's Dream (2007) is one of Woody Allen's four last movies (all made in Europe), besidesScoop, Match Point (2005), and Vicky Cristina Barcelona (2008). They have many points in common, but did not receive the same attention from the critics and the public. Both Cassandra's Dream and Match Point are thrillers, and far away from being merely entertaining. They revolve around the same existentialist conundrum made of crime, impunity and chance. Match Point, however, brought Woody Allen a wide recognition, while Cassandra's Dream failed to attain the same success. Cassandra's Dream is, nonetheless, much worthier of a critical analysis. Its characters are not so naturally constructed as the ones of Match Point. They have an imbalance, they are burlesque. But exactly because of this, Cassandra's Dream vividly exposes issues involved in all the other three movies, including Match Point. It has a key to an understanding of the jocose and apparently inane allegories about death that appear in a light hearted comedy such as Scoop. It illuminates what is opaque, irresolute and even frustrating in Vicky Cristina Barcelona, this more dark comedy.

It is known that much of Woody Allen's charm comes from his mastering of the technique of misdirection. He throws the audience off in some apparently familiar direction only to surprise it completely, on the other side of the road, where he had always been waiting for it. During the supposed walk, what happened was that the entire scenario turned 180 degrees. This is patent inCassandra's Dream. Things begin with this line of the mother, which everyone has heard: "in the end, all you have in this life that you can count on is family". As the story goes on, one is going to realize not exactly that the line is simply wrong, but that matters are more complex than they appear. Dorothy, the mother, who says the line, is first of all a very unhappy and resentful wife. She constantly deprecates her husband in front of their sons, Terry and Ian, the big and the "small stakes player". When they finally abandon the father with his small bankrupted restaurant, she stays, however, at his side and is supportive: "don't worry... I can help you if you need".

Ian and Terry move under the aegis of their uncle, an internationally successful plastic surgeon who reinforces the mother's initial line by saying to all: "you are my family". He is coming from China, and willing to help everybody financially. His apparent goodwill is nothing but the last heavy cloud in a fat storm to break out in the middle of the movie. As family, uncle Howard is the most helpful, but because he also needs you to do something he could ask nobody else. He wants, for compensation, that you get rid of one of his business partners who "knows too much". "What have you done?" - asks a bemused Terry. And the uncle raving explosion in view of such a reckless question is as fair as it is hilarious. The unveiling of Allen's misdirection inverts upside down the surface thrust of the plot. There is something of a Melinda and Melinda (Allen, 2004) here, in which the tragic turns out to be comic and vice-versa. Terry finally reflects: "family is one thing, but there are limits". But what limits? Well, "to make a big step up in life", answers Ian. It is in relation to this imperative, that there is actually no family, no God, no crossing line, "it's [just] now; it's alwaysnow". In the end of the movie, apostasy cannot be bolder. Cassandra will not prophesy, and she will not prophesy even about the future, what wouldn't apparently have any sense, but about the past. No one is going ever to solve the crime, and moreover, the unlikely but real villain, uncle Howard, will be completely freed. The conscientious brother, Terry, will take the blame for the wicked one, Ian. As in Match Point, 
there is not even a "small sign of justice". It would certainly be preposterous to attribute to Allen any kind of faith, even a negative one, and yet...

Could tragedy make any sense at all without the gods? Could there really be a tragedy when the sacrifice of the hero is not in the name of anything superior, not even family - or cynically said, blood? In Cassandra's Dream there is no hero, it's just people acting out of blind egocentric impulses and compulsion to survive. And the strength of the movie consists exactly in mirroring this absolute void. It works from what it doesn't show, and cannot show, because talk about values inevitably sounds like advertising, like trying, once more, "to make a big step up in life". And Woody Allen is faithful not to success, but to the veracity of the story he is telling, and to the cogency of its characters. There is no reason why one should take Allen's void to be more thanAnything else (Allen, 2003), although in Cassandra's Dream there isn't Billie Holiday's Easy to Love anymore, and one cannot help feeling troubled.

The two explicit references to the classic Bonnie and Clyde (1967) are misguiding. In Arthur Penn's movie, Clyde is a hero, not a villain. There is the constant feeling that "nobody gets Clyde, never", even if the couple of charming robbers are caught in the end, that is, if their dead bodies shake under an absurd burn of excessively wasted ammunition, and they go on, towards the credits. Bonnie and Clyde is more a Puritan movie than an existentialist one. They are robbers, but not debased, neither what connects them is egoistical. Clyde doesn't want to get in Bonnie's pants, and she stays with him because she is not interested in marrying a rich man. They are not there for the money at all.

It is known that, besides mastering misdirection, Allen shows a Spartan fidelity to the straight lines upon which he accommodates his punch ones. "The joke needs a true straight line... You can only go where the straight line honestly enables you to go..." (Lax, 2007: 101). Is this really what happens in Cassandra's dream? Perhaps the plot eventually forces too much against this pedestrian truism stated by the character of the opera writer in Melinda and Melinda: "life is short and not about anything, but one thing I do know is that we were not put on this Earth to be dragged all the time." Or against the other one in Scoop: "not everything in this world is sinister, just practically everything". But Allen as a director is bolder than any of his characters. Even aestheticism is deluded by him. In DeconstructingHarry (Allen, 1997), for instance, the movie could end in the scene where the writer - someone who jokingly is made to feel he is not the worse person in the world, because we have, of course, Hitler - finally got outrun by his own characters who reemerge together to save him from himself, as if in a dream, but real, and then, this is just another pun in the brain of the writer. Reality cannot be acquitted by fiction. The conundrum made of crime, impunity and chance is irremediable.

The movie that immediately followed Cassandra's Dream, that is, Vicky Cristina Barcelona, has again, as its key ingredients, sleight of hand (misdirection) and Spartan fidelity to the veracity of the plot and characters. No character here is what it appears to be, and this is why they are so true and convincing. There is always something opaque, frustrating, but nonetheless vital in each of them. Take the two businessmen, Mark and Dough. In the beginning, they look very cheap and vulgar, the opposite of the figure of the swell aristocratic father in Match Point. Mark makes harsh, coarse if funny comments. In relation to Cristina's short movie about the difficulty of defining love, he says, cuttingly: "That's a mighty big subject to handle in 12 minutes." In relation to Vicky's Master's in Catalan identity, he questions: "What do you plan on doing with that?" But as the story develops, Mark ends being the only one to be really interested in the painting given by the bohemian artist Juan Antonio and Cristina to Vicky and Dough as a wedding gift.

Mark's wife, who is far from being depicted as stupid, thinks Mark is great, and she cannot leave him. The other businessman, Dough, is this husband to be, who plays golf with his boss, and has the inane idea of getting married in Barcelona, something which "dad's contacts in the Embassy" will make "really easy", something "great to tell the kids" in the future. Arriving in Barcelona, however, Dough turns out to be indeed quite lovely, and Vicky ends marrying him. The bohemian artists, on the other hand, look like much more cultivated people, but they are also pretty uncultivated. Juan Antonio slips just too easily in the flat role of a ladies' man. He has a father who is a poet, but the point is that his father doesn't publish... Or would it be, rather, that Juan Antonio just made up the whole history in order to seduce Vicky? Later he will tell Cristina that till now, he didn't want to make love in the bedroom he used to share with his ex-wife. He changes his mind, rather quickly, when Cristina enters with him in the room. In another scene, he rubs 
a foot of the wrong woman under the table.

The other bohemian artist, Maria Helena, has fits that, as in the scene outside in the prostitutes' street, exposes her as being even pretentious, a bit of a cliché, unhappy self-destructive person, and vulgar. She is nonetheless the real genius of the story, the true outstanding personality. The most capable of affirming life besides everything, in a genuinely Bataillean, it should be pointed out, not Sartrean way. And then we have the two main characters, Vicky and Cristina. First of all, there is the ambiguity of Cristina's eyes, blue or green, and perhaps blue and green. She is not bourgeois, but she is also not a bohemian artist. She experiment with things, movies, photography, poetry, a Scriabin piano sonata - not that she could play it. Scarlett Johansson here still reminds the funny stubby finger from Scoop. Vicky, on the other hand, was the one who knew that flying to Oviedo with Juan Antonio would be a terrible mistake. But she went there anyway, and it is she who will first have sex with him. Cristina was so cool, but then she has an ulcer and can't keep her food down. She will make sex to both Juan Antonio and Maria Helena, and be the missing ingredient, the tint, the salt in their relationship, not however without first suggesting that the latter should undergone psychiatric treatment. As was so drastically explicit in Cassandra's Dream, while Vicky and Cristina go down in the airport escalation to leave Barcelona, one cannot prophesy their future. The conundrum of their lives, even if it is not made of crime, impunity and chance, remains as well irremediable.

The Ariadne's thread connecting and leading away from these riddles couldn't be found anywhere if it were not for the allegorical figure of the boat, in the light hearted Scoop. It is the irremediable pungency of Cassandra's Dream that still explains why the figure is, necessarily, allegorical. In all Allen's movies, violence and sex are always off cam. In Cassandra's Dream, not even a shot sand bag was shown. The boat of Scoop shows death itself, but not literally. It is a death that you can try to bribe, and question - not, of course, that the dark knight steering the boat will give you any answer. Nobody is ever revealed where he or she is heading. Everything remains the same, and yet it's not. After the trespass, people will keep using the same clothes, will keep having the same mundane curiosity, as when the deceased reporter says, after hearing the thrilling gossip: "what a story, this will be a dynamite scoop and I got it first!" And there is a place for the joke that "yeah, unfortunately, where you're headed, there is no first, only last..." After the ultimate storm, the creaking of the boat moving calmly under the mist instills the feeling of boredom and eternal waiting: the eternity for a card trick. As if back-mirroring the central scene of Cassandra's Dream, under the trees and the flood, where dramatic seriousness exploded into huge laugh, now light hearted comedy peers into an abyss. In both cases, one faces something rather thrilling than solemn, and black humoured. As family, afterlife can only be real by embodying the vital obsessions living people are compelled to pursue even from the grave. And obsession here means something frivolous. One would have to have preserved, for instance, his right to sleep in his own bed in the end of the day. Justice is fundamental, but a legitimate solution for the puzzling conundrums of life would have to measure up to life's frivolity as well.

In Scoop, Splendini declares he was of the Jewish persuasion, and then turned to the narcissistic one. Are not these persuasions, actually, related? Is not frivolity at the bottom of the negative kind of mysticism that is so characteristic of the Jewish faith? The long for an entirely different world that would, nonetheless, be an appropriate answer to what has always been promised here, and that we have childishly awaited? Vicky Cristina Barcelona has, on the other hand, this permanent reference to Gaudí. It is widely recognized that the works of Gaudí were motivated rather by his religious concerns than by a faith in the idea of progress, more typical of other Modernist architects such as Le Corbusier. Gaudí was entirely dedicated to the task of building his Sagrada Familia, and ended his life in isolation pursuing this aim. His peculiar ideas are known to be based in Medieval conceptions of a unity between ornamentation and construction in architecture. Gaudí's respect for the organic autonomy of architectural works has affinity with Allen's respect for the internal "needs of the creation of [a] piece of fiction" (Lax, 2007: 123). Gaudí's religion had never been Jewish, he was always a Christian. And he also believed that the greatest artistic cultures were to be developed somewhat exclusively in the Mediterranean. He was, nonetheless, very fond of an expression of St. Peter which embodies negative longings, even if making them more positive. These are Gaudí's words: "... St. Peter says that glory is the vision of God... Vision is immensity - I can see what is there and what is not there" (Crippa, 2002: 105). Woody Allen, as impossible Cassandra, enables his audience to see what is not there, even if we are all almost sure that what is not there simply doesn't exist. Or would it? 


\section{References}

Allen, Woody. Vicky Cristina Barcelona (2008).

. Cassandra's Dream (2007).

. Scoop (2006).

. Match Point (2005).

. Melinda and Melinda (2004).

. Anything Else (2003).

. Deconstructing Harry (1997).

Penn, Arthur. Bonnie and Clyde (1967).

Las, Eric. Conversations with Woody Allen, New York: Alfred A. Knopf, 2007.

Crippa, M. A. Living Gaudí, The Architect's Complete Vision. New York, Rizzoli, 2002.

\section{Author Information}

Alessandro ZIR, (PhD Dalhousie, Halifax) is a journalist and philosopher, with publications in Brazil, Chile and Portugal, including chapters of books, papers, translations, and fiction. He is a member of the GIFHC (Interdisciplinary Ground in Philosophy and History of Science), ILEA/ UFRGS - Brazil. 